\title{
Mekanisme Pembentukan Apatit pada Permukaan Sampel $\beta$-Wolastonit yang Dihasilkan daripada Abu Sekam Padi
}

(Mechanism of Apatite Formation on $\beta$-wollastonite Sample Surface Synthesized from Rice Husk Ash)

\author{
HAMISAH ISMAIL, RoSLINDA SHAMSUDIN*, MUHAMMAD AZMI ABDUl HAMID \& RozIDAWATI AwANG
}

\begin{abstract}
ABSTRAK
Mekanisme pembentukan apatit pada permukaan $\beta$-wolastonit dikaji. $\beta$-wolastonit dihasilkan daripada teknik sol-gel menggunakan abu sekam dan batu kapur terkalsin sebagai bahan pemula dengan nisbah CaO:SiO adalah $55: 45$. Kebioaktifan sampel $\beta$-wolastonit dikaji dengan merendam sampel berbentuk silinder dalam larutan simulasi badan (SBF) untuk tempoh yang ditetapkan iaitu 1, 3, 7 dan 14 hari. Komposisi permukaan, morfologi dan perubahan struktur sampel sebelum dan selepas direndam dianalisis melalui pembelauan sinar-X (XRD) dan mikroskop elektron imbasan (FESEM) yang digabungkan dengan EDX. Keputusan XRD menunjukkan fasa $\beta$-wolastonit berjaya dihasilkan selepas dimasukkan ke dalam autoklaf untuk 8 jam pada suhu $135^{\circ} \mathrm{C}$ pada tekanan $0.24 \mathrm{MPa}$ dan disinter 2 jam pada suhu $950^{\circ} \mathrm{C}$. Apatit didapati tumbuh pada permukaan sampel $\beta$-wolastonit selepas 7 hari rendaman dalam larutan SBF. Semasa proses rendaman dalam larutan SBF, 2 jenis kumpulan kalsium fosfat dihasilkan iaitu amorfus kalsium fosfat (ACP) selepas 3 hari rendaman dengan julat nisbah Ca/P 1.2-2.02 dan pada hari ke-14 membentuk hidroskiapatit kurang kalsium (CDHA) dengan nisbah Ca/P 1.63.Perubahan fasa sampel $\beta$-wolastonit daripada keadaan hablur kepada amorfus jelas terbukti daripada keputusan XRD selepas direndam dalam SBF dengan penurunan puncak keamatan bagi sampel $\beta$-wolastonit pada sudut belauan $30^{\circ}$. Ini mengukuhkan mekanisme pembentukan lapisan apatit pada permukaan sampel $\beta$-wolastonit dan ianya bersifat bioaktif.
\end{abstract}

Kata kunci: Abu sekam; apatit; batu kapur terkalsin; $\beta$-wolastonit; kebioaktifan

\section{ABSTRACT}

The mechanism of apatite formation on the $\beta$-wollastonite surface was studied. $\beta$-wollastonite was produced using the sol-gel technique from rice husk ash and calcined limestone as the starting material with CaO:SiO ratio of 55:45. Bioactivity of the $\beta$-wollastonite sample was studied by immersing a cylindrical form sample in a simulation body fluid solution (SBF) for a period of 1, 3, 7 and 14 days. Surface composition, morphology and structural of the sample before and after immersion were analyzed using X-ray diffraction (XRD) and scanning electron microscope (FESEM) cOupled with EDX. The XRD results showed that $\beta$-wollastonite was successful obtained after autoclaving for $8 \mathrm{~h}$ at $135^{\circ} \mathrm{C}$, with pressure at $0.24 \mathrm{MPa}$ and sintered for $2 \mathrm{~h}$ at $950^{\circ} \mathrm{C}$. Apatite was found to growth on the surface of $\beta$-wollastonite after 7 days of immersion in the SBF solution. During immersion in the SBF solution, two types of calcium phosphate groups were obtained, which is amorphous calcium phosphate (ACP) after 3 days of immersion with Ca/P ratio in the range of 1.2-2.02 and on the 14th day, calcium deficient hydroxyapatite (CDHA) is formed with the molar ratio Ca/P 1.63. Phase transformation from crystalline to an amorphous was clearly been detected from the XRD results through the decreasing of the peak intensity at 2 theta of $30.0^{\circ}$ after immersing in the SBF. This supports the occurring of apatite formation mechanism on the $\beta$-wollastonite surface and possesses bioactive property.

Keywords: Apatite; bioactivity; $\beta$-wollastonite; calcined limestone; rice husk ash

\section{PENGENALAN}

Kalsium silikat $\left(\mathrm{CaSiO}_{3}\right)$ atau juga dikenali dengan wolastonit adalah gabungan sebatian kalsium oksida $(\mathrm{CaO})$ dan silika $\left(\mathrm{SiO}_{2}\right)$. Kajian terhadap wolastonit masih kurang di Malaysia berbanding dengan biobahan lain seperti hidroksiapatit (Ramesh et al. 2008; Sopyan \& Jasminder 2009) dan kalsium fosfat (Sunarso et al. 2013). Kajian kalsium silikat sebagai biobahan baru dipelopori dengan menggunakan mineral tempatan iaitu pasir silika dan batu kapur tempatan dalam usaha mempelbagaikan penggunaan mineral (Rashita et al. 2014). Kalsium silikat boleh dikelaskan kepada dua keadaan bergantung kepada teknik penghasilan yang digunakan iaitu bahan biokaca dan bahan bioseramik. Kebioaktifan bahan biokaca dan bioseramik kalsium silikat sangat bagus dan setanding dengan hidroksiapatit (Shumkova et al. 2001). Selain itu, kadar jerapan yang baik dan bersifat osteogenesis menyebabkan biobahan kalsium silikat semakin hari mendapat tempat dan dijadikan sebagai bahan implan untuk tisu keras (Lin et al. 2009).

Aplikasi sekam padi dalam bidang biobahan masih baru diceburi di Malaysia. Suatu kajian telah menggunakan 
sekam sebagai bahan pengisi di dalam komposit tampalan gigi (Noor Sheeraz et al. 2013). Silika boleh diekstrak daripada sekam menggunakan teknik sol-gel dengan menggunakan $\mathrm{NaOH}$, etanol, asid hidroklorik dan asid fosforik. Keputusan yang diperoleh mendapati silika yang terhasil adalah bentuk sfera dan bersaiz nano daripada pemerhatian menggunakan TEM dan mempunyai ketulenan $99.36 \%$ bt. (Noor Sheeraz et al. 2013). Walau bagaimanapun, kajian terhadap abu sekam telah lama dijalankan di Malaysia, contohnya sebagai pengisi di dalam komposit polimer (Ismail et al. 2001), di dalam konkrit dan simen sebagai pengikat simen (Kusbiantoro et al. 2012), sebagai agen katalis (Adam et al. 2012; Daud \& Hameed 2010) dan kaca foto perdarcahaya (Lee et al. 2013). Kajian oleh Ismail et al. (2001) mendapati komposit getah asli/LLDPE abu sekam putih telah meningkatkan modulus tegangan dan kekerasan tetapi kekuatan tegangan, pemanjangan pada takat putus dan bengkak jisim merosot dengan pertambahan abu sekam putih. Kusbiantoro et al. (2012) melaporkan dalam kajian beliau mendapati interaksi antara abu sekam padi (MIRHA) dengan konkrit meningkatkan pertumbuhan gel geopolimer dan menambah baik struktur liang. Penumpatan rangka bentuk geopolimer menjadi penyumbang utama dalam meningkatkan kebolehan ikatan pengikat geopolimer tersebut. Kajian oleh Lee et al. (2013) mendapati kualiti kaca foto pendarkilau yang dihasilkan menggunakan abu sekam adalah setara dengan kaca foto pendarkilau komersial yang berada di pasaran.

Dalam kajian ini, abu sekam padi dan batu kapur terkalsin telah digunakan untuk menghasilkan $\beta$-wolastonit berpandukan gambarajah sistem $\mathrm{CaO}-\mathrm{SiO}_{2}$ (Zhao 2007) (Rajah 1). Ujian kebioaktifan dijalankan ke atas sampel $\beta$-wolastonit untuk penentuan sifat kebioaktifan apabila direndam dalam larutan SBF dan seterusnya mengkaji mekanisme pembentukan apatit pada permukaan $\beta$-wolastonit. Mekanisme pembentukan apatit pada permukaan sampel $\beta$-wolastonit abu sekam selepas proses rendaman dianalisis menggunakan ujian pembelauan sinar-X (XRD), mikroskop elektron imbasan (FESEM) yang digabungkan dengan EDX untuk menganalisis perubahan fasa, morfologi dan kandungan unsur.

\section{BAHAN DAN KAEDAH}

Sekam padi yang digunakan dalam kajian ini diperoleh dari kilang beras Ghee Seng Hong Sdn. Bhd., Pulau Pinang. Sekam terkisar yang diperoleh dari kilang beras mempunyai anggaran saiz 0.3-0.5 cm. Sekam dibakar pada suhu $950^{\circ} \mathrm{C}$ dengan kenaikan kadar pemanasan $5^{\circ} \mathrm{C} / \mathrm{min}$ dan 60 min rendaman untuk menghasilkan abu sekam. Batu kapur yang diperoleh dari Ipoh, Perak pula dikalsin pada suhu $1100^{\circ} \mathrm{C}$ dengan kenaikan kadar pemanasan $10^{\circ} \mathrm{C} / \mathrm{min}$ dan 300 min rendaman. Penentuan unsur dan fasa dalam abu sekam dan batu kapur terkalsin dianalisis menggunakan alat pendarfluor sinar-X (XRF, Bruker; S8 Tiger) dan pembelauan sinar-X (XRD, D8 Advance).

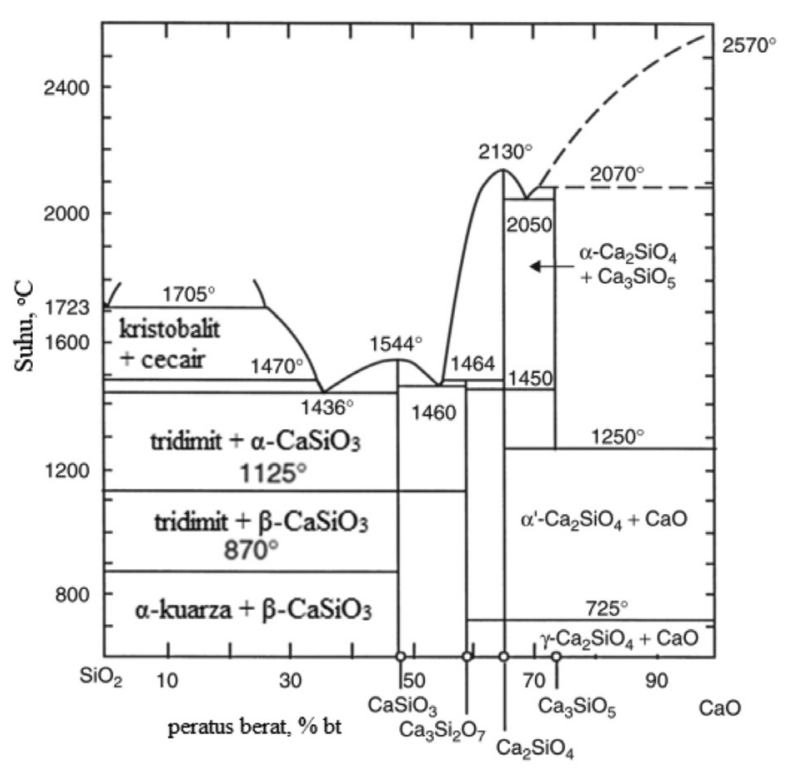

RAJAH 1. Gambarajah fasa bagi sistem $\mathrm{CaO}-\mathrm{SiO}_{2}$

Nisbah serbuk $\mathrm{CaO}: \mathrm{SiO}_{2}$ yang digunakan adalah 55:45. Serbuk batu kapur terkalsin dan abu sekam ditimbang sebanyak $10 \mathrm{~g}$ mengikut nisbah masing-masing dan dimasukkan ke dalam bikar yang diisi dengan 100 $\mathrm{mL}$ air suling. Larutan campuran dikacau menggunakan rod kaca selama 10 min sebelum dimasukkan ke dalam autoklaf selama 8 jam pada suhu $135^{\circ} \mathrm{C}$ dengan tekanan yang terhasil sebanyak 0.24 MPa. Selepas dikeluarkan daripada autoklaf, terbentuk dua lapisan iaitu lapisan bawah adalah mendakan campuran serbuk batu kapur terkalsin dan abu sekam, manakala bahagian atas adalah air suling. Lebihan air suling dibuang terlebih dahulu sebelum dimasukkan ke dalam relau untuk proses pengeringan pada suhu $90^{\circ} \mathrm{C}$ selama 24 jam. Selepas dikeringkan, hasilan dikisar menjadi serbuk menggunakan lesung akik dan disinter pada suhu $950^{\circ} \mathrm{C}$ selama 2 jam.

Serbuk yang diperoleh ditekan secara manual ke dalam acuan berbentuk silinder berukuran tinggi $12 \mathrm{~mm}$ dan diameter $6 \mathrm{~mm}$ untuk tujuan ujian kebioaktifan. Larutan simulasi badan (SBF) disediakan mengikut kaedah yang diperkenalkan oleh Kokubo dan Takadama (2006). Sampel silinder direndam dalam larutan SBF masing-masing selama $1,3,7$ dan 14 hari pada suhu $36.5^{\circ} \mathrm{C}$ di dalam inkubator. Larutan SBF ditukar setiap tiga hari, ini bagi memastikan ion-ion fosfat di dalam larutan SBF mencukupi dan sentiasa bertindak balas dengan sampel kajian dan juga untuk mengelakkan keadaan superketepuan berlaku. Nilai pH bagi larutan SBF diambil selepas selesai setiap tempoh rendaman dengan menggunakan $\mathrm{pH}$ meter (HANNA). Selepas rendaman, perubahan struktur atau fasa dikaji dengan menggunakan pembelauan sinar-X (XRD, D8 Advance), manakala morfologi dan kandungan unsur dianalisis menggunakan medan pancaran mikroskop elektron imbasan (FESEM) yang digabungkan dengan EDX (FESEM/EDX, Merlin Compact Zeiss/IncaEnergy). 


\section{HASIL DAN PERBINCANGAN}

Kandungan utama dalam sampel abu sekam padi yang dibakar pada suhu $950^{\circ} \mathrm{C}$ adalah silika $\left(\mathrm{SiO}_{2}\right)$ sebanyak $89.5 \%$ bt. dan bakinya adalah seperti $\mathrm{P}_{2} \mathrm{O}_{5}(3.61 \%$ bt. $), \mathrm{K}_{2} \mathrm{O}$ (3.36\% bt.), $\mathrm{MgO}$ (1.24\% bt.), $\mathrm{CaO}\left(0.57 \%\right.$ bt.) dan $\mathrm{Na}_{2} \mathrm{O}$ (0.35\% bt.) diperoleh daripada analisis XRF. Keputusan yang diperoleh adalah sama seperti Jenkins et al. (1998) untuk abu sekam padi yang dibakar pada $600^{\circ} \mathrm{C}$ selama 4 jam menghasilkan $\mathrm{SiO}_{2}\left(91.42 \%\right.$ bt.), $\mathrm{P}_{2} \mathrm{O}_{5}(0.43 \%$ bt. $)$, $\mathrm{K}_{2} \mathrm{O}(3.71 \%$ bt.), $\mathrm{MgO}(<0.01 \%$ bt.), $\mathrm{CaO}(3.21 \%$ bt.) dan $\mathrm{Na}_{2} \mathrm{O}(0.21 \%$ bt.). Dalam kajian ini suhu pembakaran yang digunakan adalah $950^{\circ} \mathrm{C}$ kerana suhu pembakaran $600^{\circ} \mathrm{C}$ selama 1 jam hanya menghasilkan silika sebanyak 85.99 $\%$ bt. sahaja. Menurut Kumar et al. (2012), komposisi abu sekam yang terhasil selepas pembakaran adalah dipengaruhi oleh faktor iklim, kimia tanah dan geografi kawasan penanaman padi tersebut. Silika yang diperoleh dalam kajian ini mempunyai fasa kristobalit $\left(\mathrm{SiO}_{2}\right.$, no. JCPDS: 11-0695) (Rajah 2(a)), selari dengan hasil kajian oleh Umamaheswaran dan Batra (2008) yang menyatakan sudut $21.8^{\circ}$ merupakan puncak bagi silika jenis kristobalit. Pengkalsinan batu kapur menghasilkan $97.2 \%$ bt. kalsium oksida, $2.38 \%$ bt. $\mathrm{MgO}$ dan $0.11 \%$ bt. $\mathrm{SiO}_{2}$ dengan fasa mineral yang terbentuk adalah kalsium oksida $(\mathrm{CaO}$, no. JCPDS:37-1497) dan kalsium hidroksida $\left(\mathrm{Ca}(\mathrm{OH})_{2}\right.$, no. JCPDS: 44-1481) (Rajah 2(b)). Kehadiran fasa $\mathrm{Ca}(\mathrm{OH})_{2}$ selepas pengkalsinan batu kapur mengesahkan bahawa batu kapur terkalsin bersifat hidrofilik dan batu kapur terkalsin boleh menyerap lembapan dengan cepat apabila terdedah kepada persekitaran atau kembali kepada fasa asalnya iaitu $\mathrm{CaCO}_{3}$ (Blanton \& Craig 2005).

Fasa $\beta$-wolastonit ( $\beta-\mathrm{CaSiO}_{3}$, no. JCPDS: 43-1460) terhasil apabila campuran antara abu sekam padi dengan batu kapur terkalsin disinter pada suhu $950^{\circ} \mathrm{C}$ selama 2 jam (Rajah 2(c)). Corak XRD yang diperoleh adalah serupa seperti yang dilaporkan oleh Huang dan Chang (2009) dan Wan et al. (2005). Walau bagaimanapun, teknik dan bahan mentah yang digunakan oleh penyelidik tersebut adalah berbeza tetapi tujuan utama kajian adalah untuk menghasilkan wolastonit. Huang dan Chang (2009), menggunakan teknik pembakaran gel sitrat nitrat dengan asid sitrik dan nitrat masing-masing bertindak sebagai bahan penurun pengoksidaan dan disinter pada suhu $650^{\circ} \mathrm{C}$ selama 2 jam untuk mendapatkan fasa wolastonit. Manakala kajian Wan et al. (2005) pula menggunakan teknik pemendakan secara kimia menggunakan $\mathrm{Ca}\left(\mathrm{NO}_{3}\right)_{2} \cdot 4 \mathrm{H}_{2} \mathrm{O}$ dan $\mathrm{Na}_{2} \mathrm{SiO}_{3} \cdot 9 \mathrm{H}_{2} \mathrm{O}$ sebagai bahan pemula, disinter pada suhu $800^{\circ} \mathrm{C}$ selama 2 jam dan menghasilkan fasa wolastonit monoklinik (2M).

Sifat kebioaktifan $\beta$-wolastonit dikaji secara in-situ iaitu rendaman dalam larutan SBF. Sampel $\beta$-wolastonit tanpa rendaman didapati mempunyai struktur seperti batu karang dan berliang (Rajah 3(a)) dengan kandungan unsur silikon $(\mathrm{Si})$ dan kalsium $(\mathrm{Ca})$ yang sangat tinggi iaitu 14.42 dan 15.35 manakala unsur fosforus $(\mathrm{P})$ yang rendah iaitu 2.57 (Jadual 1). Kehadiran unsur P dalam $\beta$-wolastonit sebelum rendaman adalah berasal daripada

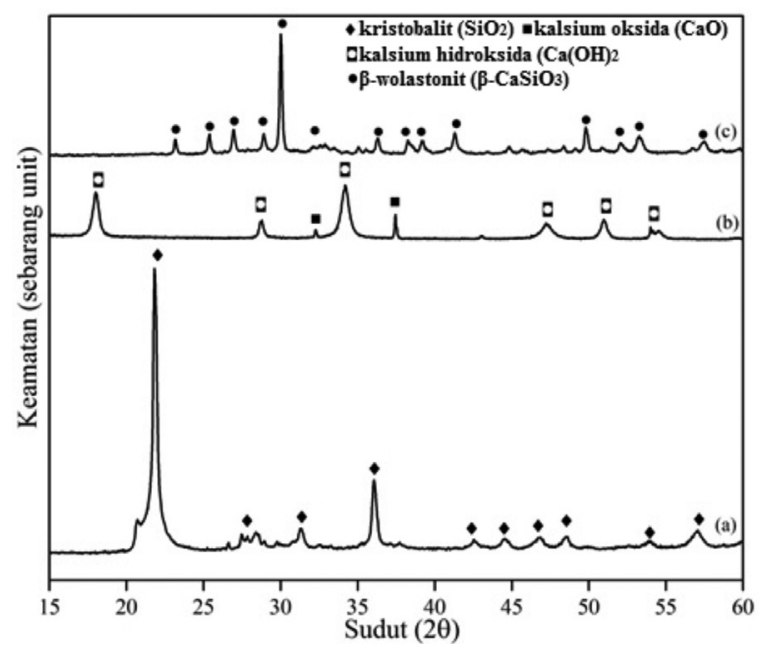

RAJAH 2. Difraktogram XRD bagi (a) abu sekam padi, (b) batu kapur terkalsin dan (c) $\beta$-wolastonit

abu sekam padi dan ini telah disahkan melalui ujian XRF yang menunjukkan kehadiran sebatian fosforus oksida $\left(\mathrm{P}_{2} \mathrm{O}_{5}\right)$ sebanyak $3.61 \%$ bt.

Komposisi dalam sampel $\beta$-wolastonit yang dihasilkan daripada abu sekam dan batu kapur terkalsin adalah hampir menyamai dengan bahan biokaca kalsium silikat yang diperoleh oleh penyelidik lain (Wan et al. 2005). Oleh itu, mekanisme tindak balas bagi kaca jenis silikat alkali dan kaca silikat alkali kapur (Li \& Zhang 1990; Liu et al. 2004) dijadikan sebagai panduan untuk mengkaji mekanisme tindak balas sampel $\beta$-wolastonit yang direndam dalam larutan SBF. Mekanisme kebioaktifan sampel $\beta$-wolastonit melibatkan dua proses iaitu pemelarutan dan pemendakan. Semasa rendaman sampel $\beta$-wolastonit dalam larutan SBF, pertamanya berlaku pembebasan ion-ion daripada sampel $\beta$-wolastonit. Oleh kerana pemelarutan ion $\mathrm{Ca}^{2+}$ dan ion $\mathrm{Si}^{4+}$ daripada sampel $\beta$-wolastonit adalah tidak sejajar, maka ion $\mathrm{Ca}^{2+}$ lebih dipilih untuk dibebaskan berbanding ion $\mathrm{Si}^{4+}$ ke dalam larutan SBF. Pembebasan ion $\mathrm{Ca}^{2+}$ menyebabkan berlakunya proses hidrolisis kumpulan silika pada sampel $\beta$-wolastonit yang menghasilkan satu lapisan kaya-silanol ( $\equiv \mathrm{Si}-\mathrm{OH})$ pada permukaan sampel $\beta$-wolastonit (Liu et al. 2004). Ion $\mathrm{Ca}^{2+}$ akan melarut ke dalam larutan SBF dan berlaku pertukaran dengan ion $\mathrm{H}^{+}$daripada larutan SBF (Mallick 2014). Bacaan $\mathrm{pH}$ didapati meningkat daripada 7.4 kepada 7.93 selepas sehari rendaman dan ini adalah disebabkan oleh proses pemelarutan ion $\mathrm{Ca}^{2+}$ daripada sampel $\beta$-wolastonit ke dalam larutan SBF (Liu et al. 2004) seperti dalam (1). Peningkatan bacaan nilai $\mathrm{pH}$ ini adalah disebabkan ion $\mathrm{H}^{+}$digantikan dengan ion $\mathrm{Ca}^{2+}$. Ion $\mathrm{Ca}^{2+}$ yang berada dalam larutan SBF tertarik secara elektrostatik kepada lapisan kaya-silanol yang baru terbentuk yang bercas negatif. Pemelarutan ion $\mathrm{Ca}^{2+}$ semakin bertambah dengan peningkatan kepekatan hidroksil daripada larutan SBF yang mana mengganggu rangkaian ikatan antara $\mathrm{Ca}$ dan $\mathrm{SiO}_{2}$ dalam sampel $\beta$-wolastonit seperti dalam persamaan 2 (Mallick 2014). 


$$
\begin{aligned}
& \equiv \mathrm{Si}-\mathrm{O}-\mathrm{Ca}-\mathrm{O}-\mathrm{Si} \equiv+2 \mathrm{H}^{+}=2 \equiv \mathrm{Si}-\mathrm{OH}+\mathrm{Ca}^{2+} . \\
& \mathrm{Si}-\mathrm{O}-\mathrm{Si}+\mathrm{H}_{2} \mathrm{O} \rightarrow \mathrm{SiOH}+\mathrm{OH}-\mathrm{Si} .
\end{aligned}
$$

Pemelarutan ion $\mathrm{Ca}^{2+}$ daripada sampel $\beta$-wolastonit dalam larutan SBF disahkan dengan peningkatan keamatan unsur P pada permukaan sampel $\beta$-wolastonit kepada 6.29 berbanding keamatan unsur $\mathrm{Si}$ dan $\mathrm{Ca}$, masing-masing 5.75 dan 7.47 (Jadual 1). Ia turut memberi kesan kepada morfologi sampel $\beta$-wolastonit dan ia berubah daripada struktur batu karang kepada struktur gugusan selepas sehari rendaman dalam larutan SBF (Rajah 3(b)). Tiada perubahan fasa yang nyata dikesan pada sampel $\beta$-wolastonit selepas sehari rendaman sebagaimana ditunjukkan pada spektrum XRD (Rajah 4(a)).

Pada hari ke-3 rendaman, bacaan $\mathrm{pH}$ larutan SBF terus meningkat kepada 8.24 akibat daripada pemelarutan berterusan ion $\mathrm{Ca}^{2+}$ ke dalam larutan SBF. Langkah seterusnya, ion $\mathrm{Ca}^{2+}$ yang tertarik kepada permukaan bercas negatif $\equiv \mathrm{Si}^{-} \mathrm{O}^{-}$akan mula termendap pada permukaan tersebut dan diikuti oleh penjerapan ion $\mathrm{PO}_{4}^{3-} / \mathrm{HPO}_{4}{ }^{2-}$ di atas ion $\mathrm{Ca}^{2+}$. Kandungan unsur $\mathrm{Ca}$ dan $\mathrm{P}$ terus meningkat dengan pesat selepas tiga hari rendaman masing-masing kepada 13.53 dan 7.25 tetapi unsur Si mengalami penurunan kepada 5.21 (Jadual 1). Peningkatan mendadak nilai $\mathrm{pH}$ boleh dikaitkan dengan peningkatan kandungan unsur $\mathrm{Ca}$ dan $\mathrm{P}$ akibat daripada proses pemelarutan dan pemendapan yang berlaku semasa proses rendaman sampel $\beta$-wolastonit dalam larutan SBF. Pemendapan ion $\mathrm{Ca}^{2+}$ telah menghasilkan satu lapisan nipis amorfus jenis kalsium fosfat (ACP) yang terbentuk melapisi struktur batu karang pada permukaan sampel $\beta$-wolastonit seperti dalam Rajah 3(c). Pembentukan lapisan amorfus jenis kalsium fosfat (ACP) disahkan oleh nisbah $\mathrm{Ca} / \mathrm{P}$ iaitu 1.87. Menurut Cölfen (2010), nisbah $\mathrm{Ca} / \mathrm{P}$ untuk lapisan amorfus jenis ACP adalah antara julat 1.2-2.2, walau bagaimanapun, fasa lapisan amorfus jenis kalsium fosfat ini tidak dapat dikesan menggunakan XRD kerana strukturnya seperti lapisan kekaca yang bersifat amorfus. Oleh itu, hanya corak pembelauan fasa $\beta$-wolastonit berhablur sahaja yang dikesan (Rajah 4(b)).

Lapisan amorfus ACP yang terbentuk ini didapati semakin menebal dan menutupi hampir keseluruhan permukaan sampel $\beta$-wolastonit yang telah direndam selama 7 hari (Rajah 3(d)). Morfologi permukaan sampel $\beta$-wolastonit yang diperoleh ini disahkan daripada peningkatkan kandungan unsur $\mathrm{Ca}, \mathrm{P}$ dan $\mathrm{Si}$ kepada 18.78, 9.31 dan 7.12 (Jadual 1) pada hari ke-7 rendaman. Peningkatan ketebalan lapisan amorfus jenis ACP ini juga turut disokong daripada nilai nisbah $\mathrm{Ca} / \mathrm{P}$ yang meningkat kepada 2.02. Spektrum XRD pula menunjukkan penurunan keamatan puncak fasa $\beta$-wolastonit pada sudut $30^{\circ}$ (Rajah 4(c)) disebabkan oleh kehadiran lapisan amorfus ACP yang semakin menebal (Rajah 3(d)). Puncak spektrum XRD bagi hidroksiapatit (HA) mula dikesan pada hari rendaman ke-7 pada sudut belauan antara $31.0-35.0^{\circ}$ dan ini juga merupakan faktor penyumbang kepada penurunan puncak fasa $\beta$-wolastonit pada sudut $30.0^{\circ}$.

Selepas hari ke-7 rendaman, lapisan amorfus jenis ACP berkurangan dan fasa hidroksiapatit kurang kalsium (CDHA) mula terbentuk (Rajah 3(e)). CDHA terhasil daripada penggabungan lapisan ACP iaitu Ca- $\mathrm{P}_{2} \mathrm{O}_{5}$ pada permukaan sampel $\beta$-wolastonit dengan anion $\mathrm{OH}^{-}$daripada larutan SBF. Nilai pH mengalami penurunan daripada 7.93 kepada 7.80 akibat daripada pembentukan apatit pada permukaan sampel $\beta$-wolastonit. Pembentukan fasa CDHA ini disahkan oleh nisbah $\mathrm{Ca} / \mathrm{P}$ iaitu 1.63 , memenuhi nisbah $\mathrm{Ca} / \mathrm{P}$ untuk pembentukan fasa CDHA yang berjulat 1.5-1.67 (Dorozhkin 2010). Kandungan unsur Ca dan P juga meningkat dengan tempoh rendaman kepada 18.27 dan 11.21, manakala kandungan unsur Si menurun kepada 6.67 (Jadual 1).

Mekanisme pembentukan apatit pada permukaan sampel $\beta$-wolastonit saling dipengaruhi oleh perubahan nilai $\mathrm{pH}$ dan kepekatan ion larutan SBF sebagai mana yang dilaporkan oleh Dorozhkin (2010) dan Zhao dan Chang (2004). Tetapi dalam kajian ini tiada pengujian kepada ion larutan SBF dijalankan kerana larutan SBF ditukar setiap 3 hari untuk mengelakkan larutan SBF menjadi tepu. Pengesahan kehadiran fasa hidroksiapatit ini telah disahkan oleh spektrum XRD yang menunjukkan kehadiran fasa hidroksiapatit pada sudut belauan $31-35^{\circ}$ dan nisbah $\mathrm{Ca} / \mathrm{P}$ yang diperoleh adalah 1.63 setara dengan nilai $\mathrm{Ca} / \mathrm{P}$ untuk kumpulan kalsium fosfat jenis hidroksiapatit kurang kalsium (CDHA) iaitu 1.5-1.67 (Dorozhkin 2010). Di samping itu, keputusan ini turut diperkukuhkan lagi dengan perolehan bacaan nilai $\mathrm{pH}$. Nilai $\mathrm{pH}$ bagi kumpulan ACP dan CDHA masing-masing adalah dalam julat 5.0-12.0 dan 6.59.5 (Dorozhkin 2010). Manakala bacaan pH bagi larutan SBF yang diperoleh dalam kajian ini adalah 7.4-8.3 setara dengan nilai $\mathrm{pH}$ bagi CDHA. Oleh itu boleh disimpulkan

JADUAL 1. Nilai pH dan kandungan unsur Si, Ca dan P pada permukaan sampel $\beta$-wolastonit sebelum dan selepas rendaman dalam larutan SBF

\begin{tabular}{cccccc}
\hline \multirow{2}{*}{$\begin{array}{c}\text { Hari } \\
\text { rendaman }\end{array}$} & $\mathrm{pH}$ & \multicolumn{3}{c}{ Kandungan unsur (berat atom) } & \multirow{2}{*}{$\mathrm{Ca} / \mathrm{P}$} \\
\cline { 3 - 5 } & & $\mathrm{Si}$ & $\mathrm{Ca}$ & $\mathrm{P}$ & \\
\hline 0 & 7.40 & 14.42 & 15.36 & 2.57 & - \\
1 & 7.93 & 5.75 & 7.47 & 6.29 & 1.19 \\
3 & 8.24 & 5.21 & 13.53 & 7.25 & 1.87 \\
7 & 7.93 & 7.12 & 18.78 & 9.31 & 2.02 \\
14 & 7.80 & 6.67 & 18.27 & 11.21 & 1.63 \\
\hline
\end{tabular}



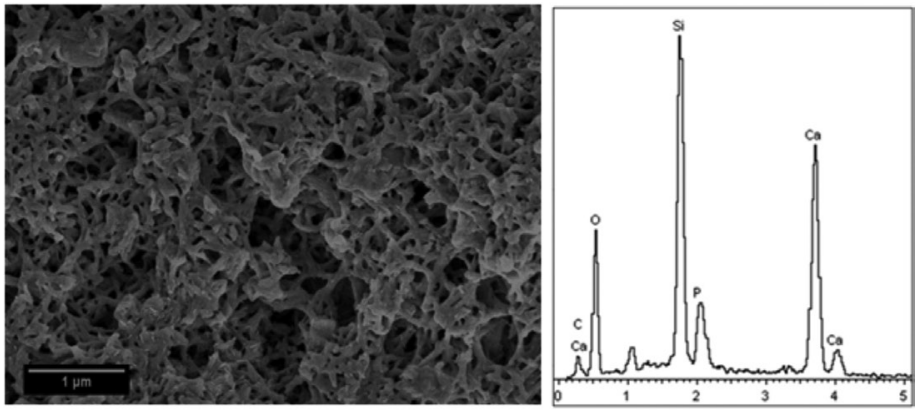

(a)
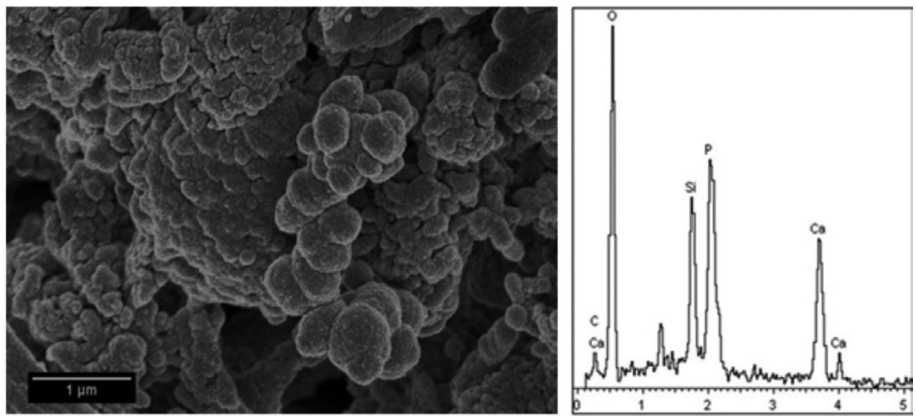

(b)
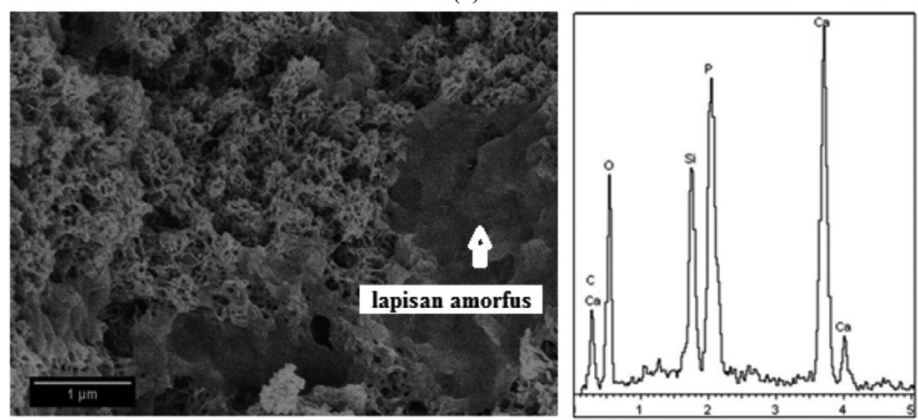

(c)
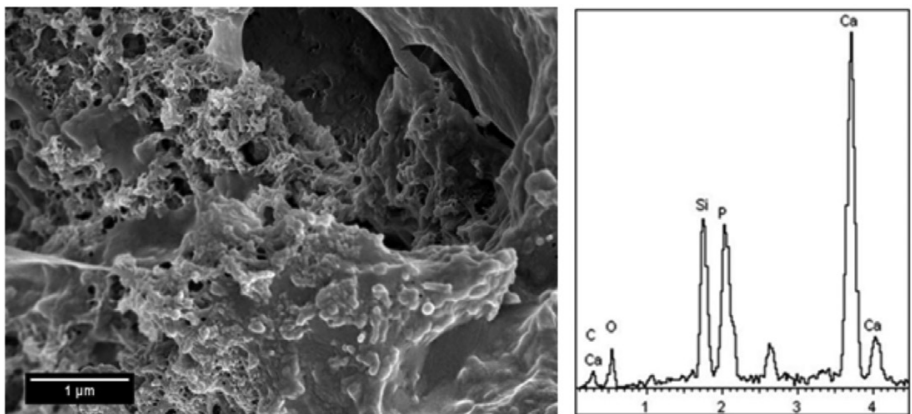

(d)
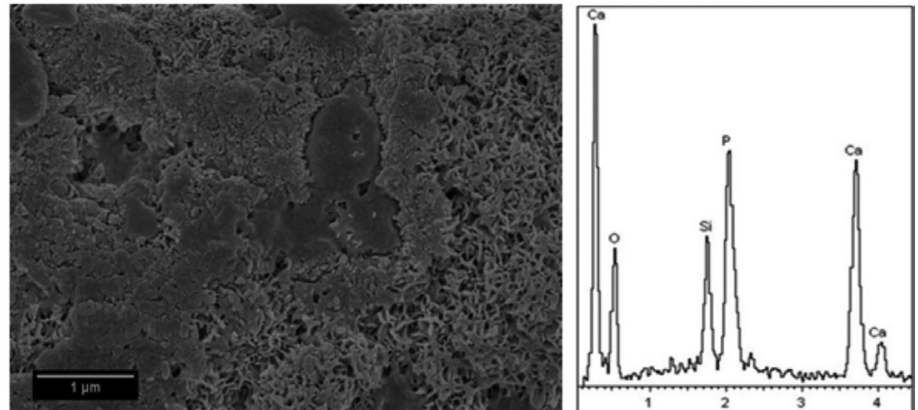

(e)

RAJAH 3. Morfologi dan spektrum EDX bagi sampel $\beta$-wolastonit (a) sebelum dan selepas direndam dalam larutan SBF untuk tempoh (b) 1, (c) 3, (d) 7 dan (e) 14 hari 


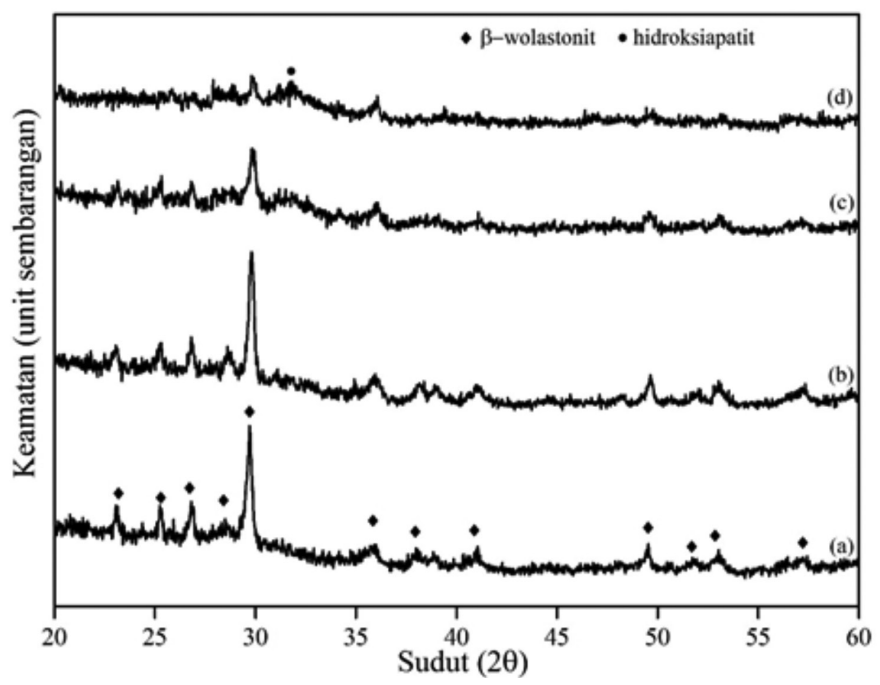

RAJAH 4. Difraktogram XRD bagi sampel $\beta$-wolastonit yang direndam dalam larutan SBF untuk tempoh (a) 1, (b) 3, (c) 7 dan (d) 14 hari

daripada hasilan kajian yang diperoleh menunjukkan kumpulan kalsium fosfat yang terhasil daripada pengujian sifat kebioaktifan sampel $\beta$-wolastonit adalah jenis CDHA. Fasa ACP merupakan fasa tidak stabil dan secara semula jadi akan berubah kepada fasa CDHA selari dengan tempoh rendaman dalam larutan SBF (Dorozhkin 2010).

\section{KESIMPULAN}

Apatit terbentuk pada permukaan sampel $\beta$-wolastonit apabila direndam dalam larutan SBF. Mekanisme pembentukan apatit pada permukaan sampel $\beta$-wolastonit adalah sama dengan mekanisme pembentukan apatit bagi bahan biokaca kalsium silikat. Rendaman sampel $\beta$-wolastonit dalam larutan SBF menghasilkan dua jenis kumpulan kalsium fosfat iaitu amorfus kalsium fosfat (ACP) yang bersifat tidak stabil dan hidroksiapatit kurang kalsium (CDHA). Nilai pH larutan SBF bergantung kepada kehadiran ion daripada sampel $\beta$-wolastonit dan larutan SBF. Ini menunjukkan bahawa sampel $\beta$-wolastonit yang dihasilkan ini adalah bersifat bioaktif.

\section{PENGHARGAAN}

Terima kasih kepada Kementerian Sains, Teknologi \& Inovasi (MOSTI) yang membiayai projek penyelidikan melalui peruntukan geran FRGS/2/2013/SG06/UKM/02/6, Kementerian Pengajian Tinggi yang menaja pengajian kajian penyelidikan ini melalui peruntukan MYPhD dan Fakulti Sains \& Teknologi, UKM.

\section{RUJUKAN}

Adam, F., Jimmy, N.A. \& Anwar, I. 2012. The utilization of rice husk silica as a catalyst: Review and recent progress. Catalysis Today 190: 2-14.

Blanton, T.N. \& Craig, L.B. 2005. Quantitative analysis of calcium oxide desiccant conversion to calcium hydroxide using X-ray diffraction. International Centre for Diffraction Data 48: 45-51.

Cölfen, H. 2010. Biomineralization: A crystal-clear view. Nature Materials 9: 960-961.

Daud, N.K. \& Hameed, B.H. 2010. Decolorization of acid red 1 by fenton-like process using rice husk ash-based catalyst. Journal of Hazardous Materials 176: 938-944.

Dorozhkin, S.V. 2010. Bioceramics of calcium orthophosphates. Biomaterials 31: 1465-1485.

Huang, X.H. \& Chang, J. 2009. Synthesis of nanocrystalline wollastonite powders by citrate-nitrate gel combustion method. Materials Chemistry and Physics 115: 1-4.

Ismail, H., Nizam, J.M. \& Abdul Khalil, H.P.S. 2001. The effect of a compatibilizer on the mechanical properties and mass swell of white rice husk ash filled natural rubber/linear low density polyethylene blends. Polymer Testing 20: 125-133.

Jenkins, B.M., Baxter, L.L., Miles Jr, T.R. \& Miles, T.R 1998. Combustion properties of biomass. Fuel Processing Technology: 54(1): 17-46.

Kokubo, T. \& Takadama, H. 2006. How useful is SBF in predicting in vivo bone bioactivity? Biomaterials 27: 2907 2915.

Kumar, A., Mohanta, K., Kumar, D. \& Parkash, O. 2012. Properties and industrial applications of rice husk: A review. International Journal of Emerging Technology and Advanced Engineering 2: 86-90.

Kusbiantoro, A., Muhd Fadhil, N., Nasir, S. \& Sobia, A.Q. 2012. The effect of microwave incinerated rice husk ash on the compressive and bond strength of fly ash based geopolymer concrete. Construction and Building Materials 36: 695-703.

Lee, T., Radzali, O. \& Yeoh, F-Y. 2013. Development of photoluminescent glass derived from rice husk. Biomass and Bioenergy 59: 380-392.

Li, P. \& Zhang, F. 1990. The electrochemistry of a glass surface and its application to bioactive glass in solution. Journal of Non-Crystalline Solids 119: 112-118.

Lin, K., Jiang, C., Ziwei, L., Yi, Z. \& Ruxiang, S. 2009. Fabrication and characterization of 45S5 bioglass reinforced macroporous calcium silicate bioceramics. Journal of the European Ceramic Society 29: 2937-2943. 
Liu, X., Ding, C. \& Chu, P.K. 2004. Mechanism of apatite formation on wollastonite coatings in simulated bodyfluid. Biomaterials 25: 1755-1761.

Mallick, K. 2014. Bone Substitutes Materials.1st ed. Cambridge: Woodhead publishing in series biomaterials. Number 78

Noor Sheeraz, C.Z., Ismail, A.R., Dasmawati, M. \& Adam, H. 2013. A green sol-gel route for the synthesis of structurally controlled silica particles from rice husk for dental composite filler. Ceramics International 39: 4559-4567.

Ramesh, S., Tan, C.Y., Bhaduri, S.B., Teng, W.D. \& Sopyan, I. 2008. Densification behaviour of nanocrystalline hydroxyapatite bioceramics. Journal of Materials Processing Technology 206: 221-230.

Rashita, A.R., Roslinda, S., Muhammad Azmi, A.H. \& Azman, J. 2014. In-vitro bioactivity of wollastonite materials derived from limestone and silica sand. Ceramics International 40: 6847-6853.

Shumkova, V.V., Pogrebenkov, V.M., Karlov, A.V., Kozik, V.V. \& Vereshchagin, V.I. 2001. Hydroxyapatite-wollastonite bioceramics. Glass and Ceramics 57: 350-353.

Sopyan, I. \& Jasminder, K. 2009. Preparation and characterization of porous hydroxyapatite through polymeric sponge method. Ceramics International 35: 3161-3168.

Sunarso, Ahmad Fauzi, M.N., Shah Rizal, K., Radzali, O., Ika, D.A. \& Ishikawa, K. 2013. Synthesis of biphasic calcium phosphate by hydrothermal route and conversion to porous sintered scaffold. Journal of Biomaterials and Nanobiotechnology 04: 273-278.
Umamaheswaran, K. \& Batra, V.S. 2008. Physico-chemical characterisation of Indian biomass ashes. Fuel 87: 628-638

Wan, X., Chengkang, C., Dali, M., Ling, J. \& Ming, Li. 2005. Preparation and in vitro bioactivities of calcium silicate nanophase materials. Materials Science and Engineering: C 25: 455-461.

Zhao, J.C. 2007. Methods for Phase Diagram Determination. New York: Elsevier.

Zhao, W. \& Chang, J. 2004. Sol-gel synthesis and in vitro bioactivity of tricalcium silicate powders. Materials Letters 58(19): 2350-2353.

Pusat Pengajian Fizik Gunaan

Fakulti Sains dan Teknologi

Universiti Kebangsaan Malaysia

43600 Bangi, Selangor Darul Ehsan

Malaysia

*Pengarang untuk surat-menyurat; email: linda@ukm.edu.my

Diserahkan: 8 Oktober 2015

Diterima: 25 Mac 2016 